\title{
Breve af Godfred Rode.
}

\section{Ved Elise Bockelund.}

Godfred Rode, af hvem der her skal bringes 6 Breve, virkede $1^{1 / 2}$ Aar som Lærer ved Rødding Højskole. (1851-52).

Brevene er skrevet til Fru Vilhelmine Hage, f. Faber, g. m. Storkøbmanden og Politikeren Konsul Alfred Hage. Rode havde undervist Dotrene i det Hageske Hjem. Af disse nævnes i Brevene: Elise, senere gift med Digteren og Politikeren Carl Ploug, og Hanne, senere gift med Billedhuggeren Vilhelm Bissen. Christopher var den xldste Søn, han faldt i 64 .

Brevene giver et Indtryk af Brevskriverens digterisk bevægede Sjæl og ædle, men noget vege Karakter og af den store Hengivenhed, han nærede for det Hages'ke Hjem, der paa saa mange øvede en mægtig Indflydelse, ikke mindsf ved Husfruens rige Evner og varme Hjerte.

Chr. Richardt, den bekendte Digter, vár Godfred Rodes nære Ven. Forstanderen var Sofus Høgsbro, den senere kendte Politiker. D. G. Monrad, Biskop, senere Minister, stod dengang som Oppositionens Fører mod Ministeriet Bluhme. Carl Moltke (Nütschau) var Minister for Slesvig og forte et strengt Herredømme, H. N. Clausen, theologisk Professor, en af de nationalliberale Førere og en tro Ven af Dauskheden i Sønderjylland.

Brevene fortæller en Del om Livet paa Rødding Højskole i dens første Tid, om sønderjydske Stemninger og om den unge københavnske Students oprigtige Forsøg paa at leve sig ind $i$ Forholdene og udrette noget.

Af Brevene er udeladt noget, der kun har privat Interesse, og desuden nogle uforbeholdne Udtalelser om Personer, Brevskriveren ikke levede paa nært Hold af.

Godfred Rode var født i Vallø 1830 som Søn af Stiftsforvalter, Justitsraad J. L. R. Efter at have fuldendt sit Studium 
$1864 \mathrm{og}$ vundet Doktorgraden 1866 virkede han som Larer $\mathrm{i}$ nogle Aar og endte sine Dage 1878 som Forstander for Højskolen Skovgaard paa Sjælland. I Agteskab med Orla Lehmanns l)atter Margrethe blev han Fader til Politikeren Ove Rode ogDigteren Helge Rode.

Nr. 1. Vallø, 22-5-1851.

[Tak for Fru Hages sidste Brev, hvori hun meddeler om private Forhold.] _ - - Ja, De m a a undskylde mig; men jeg har faaet Deres Brev i dette Øjeblik; jeg følte straks Trang til at skrive, og nu er jeg saa fuld af Spørgsmaal. Det er ogsaa harmeligt, at der ikke virkelig findes Syvmilestøvler, for saa kunde jeg netop i et Skridt være hos Dem; og saa deelte De jo nok lidt med mig - - - [G. R. har Haab om at deltage i det skandinaviske Studentermøde i Norge.] - Uendelig mange Tak for Deres næstsidste Brev, for Underretningen om de dengang Fraværende, for Deres skjønne Beskrivelse af StokkerupLivet, som vil sætte mig tilbage i kjere Stemninger fra ifjor; men fremfor Alt Tak fordi De tænker paa mig og tænker saa moderligt paa mig. De opfordrer mig til et grundigt Studium af de Sprog, jeg giver mig af med, og De kan ogsaa være vis paa, at dette skeer, hvad Islandsken angaaer; men behandle mere end een Ting grundigt ad Gangen, er $\mathrm{m}$ i g umulig, og De veed desuden nok, at det er de gamle Sprog, der drager mig meest; saa Engelsken driver jeg ikke saa stærkt og forlanger heller ikke mere Kundskab deri, end at jeg kan have Adgang til dens Literatur, og at det maaskee kan hjælpe mig, dersom jeg engang faaer fat paa Angelsachsisk. Men De maae ikke see suurt til, at jeg ikke saa Lidet beskjæftiger mig med at lære ınit Fødelands skjønne Literatur at kjende, til hvilken min Kjendskab for har været altfor ringe endog kun for mig i Egenskab af Dansk, sige mere af dansk Sprogmand, og af Poet. i Haabet (dette Sidste siger jeg kun til Dem). De vil ikke forbyde mig at drømme, og det lader jeg heller ikke være, dertil ere vore Skove for dejlige, og dertil er Stranden altfor præg- 
tig, naar jeg seer den paa mine V'andringer, og naar jeg hyppig ikke kan lade være at gaa ned til den, skjøndt den da ikke er Noget mod Stokkerups, men ikke destomindre har jeg ikke skrevet et eneste Vers herude endnu, er det ikke godt? Jeg vil haabe, at jeg ikke kan lade vaere, naar jeg kommer fra Norge, dersom jeg kommer med der, hvad dog nok er højst tvivlsomt. Det er formøjeligt at see og høre, hvorledes Tanken vender sig overalt bort fra Tydskland og mod England; maatte kun de skandinaviske Tanker ikke blive glemte; dem skulde nu Norgesrejsen hjælpe til at opfriske og styrke. Jeg tænker Ploug vil gribe sig alı; det har glædet mig at høre, at han skal være saa elsket, næsten forgudet af de svenske Bradre.

Nr. 2 Rødding Højskole, 25-11-185̆1.

Ikke sandt, kjere Fru Hage, De har engang imellem selv i Deres travle Flyttetid tæukt paa mig, paa hvorledes jeg havde det, om jeg var tilfreds i min nye Virksomhed, om jeg havde det hyggeligt $i$ min lille Stue, og ønsket Brev fra mig for at høre lidt derom, ikke sandt, det har De gjort? Jeg gjør Fordring paa, at saadanne Tanker have været hos Dem, jeg, sonı hver Dag sender tusende Tanker til Dem og Deres, jeg, som kan fortælle flere Beviser paa, at jeg er Dem kjer, jeg, hvem De $i$ et Brev, som ligger for mig, har kaldet "det fjerde Blad« $i$ Deres Fiirkløver,") det holder jeg mig til og skriver. Ja, tilvisse er jeg tilfreds i min Virksomhed. Selv at beskjæftige mig idelig med mit Fødelands Literatur og bibringe Andre Kundskab om den og Kjærlighed til den, det maa vel sagtens kunne behage mig, er det ikke en væsentlig Hjælp til at styrke Fædrelandskjærligheden, og maa jeg ikke være stolt af eller i det mindste lykkelig ved saaledes at kumne bidrage mit til et heldigt Udfald af den store Kamp imellem Dansk og Tysk, denne Kamp, som ingen Diplomater og ingen Stormagter skal gjøre Tysker har sit Fædreland Norden for Ejderen, eller -- - indtil

*) Hages havle tre Sonner. 
Fnde paa, men som skal vare ved, saalænge indtil der ingen ler ingen Dansk er i Danmark. Ja, vist er jeg tilfreds, og dog naar man kommer med altfor stor Begejstring og altfor ideale Drømme, saa faaer man slemt paa Hovedet engang imellem; mange af disse gode Mennesker komme jo hertil alene for at lare Ting, som kan være den til ligefrem Nytte i deres Haandtering; hos dem maa Sandsen for det Højere, for det Aandelige forst vækkes, og inden dette sker, faaer man jo en og anden lille Sorg; men det forstaar sig, mærker man saa forst, at det lykkes, bliver Glæden jo ogsaa desto større. Et Slag har jeg allerede leveret Tydskheden her, og det et Slag i aaben Mark, thi ellers gaar det jo kun ved Skjærmydsler og idelige Udfald (De forstaaer mig, der er ingen Tydske paa Skolen, men det er Tanken om Tydskermes Fortrinlighed og Nadvendighed, som skal udryddes), men det var dette Slag i aaben Mark, jeg vilde omtale, hvori jeg desvarre neppe sejrede, i det mindste ikke fuldstændig. Paa Højskolen læres ikke Tydsk, men privat kan d e faae Undervisning deri, som onske det. Nu skete det, at Mange erklærede heller at ville lære Tydsk end Engelsk, hvorfor jeg efter Aftale med Forstanderen holdt en Tale til dem, hvori jeg udtalte, at det havde gjort mig ondt at høre dette, deels fordi jeg deraf kunde slutte, at Nogle af dem gik med mindre Lyst til den engelske Indervisning, og dette nødvendig maatte virke skadeligt paa det Hele, men isærdeleshed, fordi jeg troede, at navnlig for Slesvigerne maatte det være blevet indlysende, efterat en treaarig Krig med dens Ulykker havde hvilet over Landet, hvor liden Glæde Danmark havde havt af sit Samkvem med Tydskland, saa at man ikke skulde troe, at de vilde gjøre Noget for at vedligeholde det, og det gjorde de ved at lære Tydsk, og derved vise Tydskerne, at de nødig vilde undvære dem; naar Tydskerne vilde have Noget med dem at gjøre, saa kunde de lære Dansk o. s. v. Jeg omtalte desuden, at de kunde faae mere Glæde af (den*) nu aabnede engel-

*) I Forauret 1851 var en Dampskibsforbindelse aabnet mellem Lowestoft (England) oo Hjerting-Ballum. ("Fæadrelandet《 $8 / 4 \quad 1851$. Sandsynligvis er det hertil, R. sigter. 
ske Handel, og talte virkelig varnit og indtrængende, det kunde jeg godt føle. Imidlertid 8 af de 33 havde meldt sig til Tydsk; om jeg nu har faaet En og Anden til at lade være, det veed jeg jo ikke; men paa den anden side naar disse unge Menneskers Forældre have sagt dem, at de skulle lære Tydsk, hvad skal de saa gjøre. Da ingen af os Lærere vilde paatage sig Undervisningen i Tydsk, har Fru Thomsen (Inspektørens Kone) maattet overtage det. Forresten lægger jeg mig efter at synge tydske Sange. De studser, jo Thomsen og jeg indøver Duetter af Mendelsson Bartholdy, for den smukke Musiks skyld gjør jeg det; men jeg synger ogsaa Kæmpeviser, Thomsen spiller Nogle og til andre accompagnerer Fru Thomsen mig; vil De fortælle Elise, at hun holder mest af at faae alle Versene. Med Elevernes Sangundervisning gaaer det hidindtil kun smaat, da jeg endnu intet Instrument har, og det er besværligt at lære dem en ny Sang ved Stemmen alene; vi har derfor meest sunget fædrelandske Sange, som de Fleste kjendte efter Boisens Visebog. Een Kæmpevise har jeg dog lært dem, og det er "Hr. V'illemand og hans Mø saa puur«, da de skal lære et Par vartouske Psalmer, og deriblandt "Guds Menighed«. Jeg er nemlig ogsaa Præst her paa Gaarden [Kritik over den stedlige Præst] - derfor holdes der hveranden Søndag, naar der er sidste Prædiken i Byen, en Slags Gudstjeneste, som bestaaer i Afsyngelsen af et Par Psalmer og Oplæsning af en Prædiken; jeg havde havt $i$ Sinde at læse Grundtvigs Prædikner, men troer de er for svare for dem at forstaae, desuden følger han ikke Evangelierne, hvilket jeg antager at disse Tilhører helst ønske.

I Søndags 8 Dage læste jeg derfor en af Mynsters en meget smuk Prædiken om den Bøn: "Forlad os vor Skyld, som vi forlade vore Skyldnere«. En Kæmpevise har jeg dog lært dem til, nemlig "jeg gik mig ud en Sommerdag at høre", naturligvis med Grundtvigs Ord, saaledes som de findes i Boisens Bog. Med Engelsken kniber det jo lidt at faae dem givet et Begreb om Udtalen. 
Hvad min lille lavttilloftede Stue angaar, saa haaber jeg nok at faa den hyggelig, naar jeg faaer et Gulvtæppe og et Claver, som endnu ikke ere ankomne. Det lille Maleri, De forserede mig, pynter ikke daarligt. Samme Maleri gjør mig megen Glæde, jeg søger at gjøre mig fortrolig med den Tanke, at det netop er Stokkerup Skrænt, der er malet, skønt det jo ikke ganske ligner den; det lille Hus, som De maaskee erindrer, titter frem ved den ene Side, forvandler sig saa til Lysthuset $i$ Deres Have, og saa staaer jeg og tænker, mon dog Drengene ikke skulde komme kilende ned og see efter Tordenstene og Rav, eller mon jeg dog ikke skulde see et eller andet kvindeligt Hoved titte frem over Skrænten og hvad er lettere for min Phantasi end at lade det skee, som jeg ønsker. Men jeg taler, som om jeg behøvede et synligt Minde for at være Dem nær; nej, tro mig, min Tanke er hvert Øjeblik i Deres Nærhed, lydlost, stille svæver den om, De aner den mangen Gang ikke, men den er der dog, den tager Deel i enhver af Deres ModerGlæder og Sorger, den lytter opmærksom til Elises Sang, seer glad paa Hannes Dands, kort den følger Deres hele Huus og glæder sig over det skjønne Liv, der rører sig imellem dem. Fra min trofaste Christian Richardt har jeg i disse Dage havt Brev, det bestaaer mest $i$ en Udtalelse af hans Henrykkelse over at have været i Deres Huus, hans Veemod ved at skilles fra Dem, og hans Tilfredshed ved dog at have et bestemt Tilknytningspunkt, nogle ugentlige Undervisningstimer. Det gaar ham son mig. Tak for den Hilsen, De deri sender mig, snart haaber jeg at faae et Par Ord fra Dem; De veed, hvor kjerkomne de er mig.

Nr. 3 Rødding Højskole, den 1ste Januar 1852.

Glædeligt Nytaar, kjere Fru Hage, jeg er desværre kommen for silde til at sige Glædelig Juul, ja alt for lang Tid er gaaet hen, uden at jeg har takket Dem for Deres saa kjere Brev, for Alt hvad De fortæller mig om Dem og Deres, hos hvem mine Tanker stadig færdes og som jeg ogsaa seer ikke glem- 
mer mig, skjøndt den Tid snart er fjerı, da jeg daglig var Dem nær, ja Tak, fordi De vedbliver at holde af mig, maatte min Handlen og Virken bestandig gjore mig værdig dertil.

Mit Liv herovre gaar naturligvis den samme jævne Gang, ja, det vil da sige, at vi har jo havt Juleferie, og vi har den da endnu. I den har Thomsen og jeg aflagt et Besog hos to Præstefamilier; hos den ene Familie, som boede i Jylland (jeg fandt det ganske morsomt igjen at befinde mig i Kongeriget) var der Børn, og hos den anden her i Slesvig var desuden to voxne Døttre, nette unge Piger, begge Dele var mig en sand Vederkvægelse at see og omgaaes, og vilde have været det endnu mere, hvis jeg ikke havde lidt af en ulidelig Ørepine, som endnu ikke ganske er overstaaet. Ja, hvor taknemlig, jeg end er for de Mennesker jeg boer iblandt, saa ere de mig for faa, en Mand og en Kone er ikke nok til at udgjøre et Familieliv. ...... Fru Hage, jeg er blevet forvænt hos Dem, naar faaer jeg Stokkerup og Stokkerups Dage igjen. Dog troe ikke, jeg er utilfreds med min Lod, langtfra, jeg er dog inderlig taknemlig, men lidt Hjemvee og lidt Længsel efter Venner, ja selv meget af Begge, ere jo dog tilladelige Følelser.

Jeg har nu faaet et Claver, ja, det er nu til Dem jeg gjør vedkommende Instrument den Fre at kalde det et Claver. Min Fader har en stor Kasse, hvori han gjemer Søm, S t a a 1 t r a a d og deslige; naar man støder til den eller rører lidt om i den frembringer den Lyd; noget lignende er dette Claver, det vil sige under al Kritik, saa at jeg ikke gider spille paa det. Imidlertid bruger jeg det dog til to Gange om Ugen at lære et Udvalg af de bedste Stemmer blandt Eleverne tostemmige Sange, hvilket jeg haaber skal komme til at gaae. Jeg lærer dem da ogsaa nye Melodier eenstemmige; De forstaaer, at dette er udenfor den egentlige Skoletid paa mit eget Værelse; i de bestemte Sangtimer gjennemgaaes da de nylærte Sange, som Resten af Eleverne saa stræbe at lære. Sangundervisningen gjør mig megen Glæde, der er adskillige flinke Stemmer og det gaaer med Lyst. Naar jeg da tænker paa, hvorledes Kæmpeviserne. 
af hvilke jeg især søger at lære dem rigtig mange, naar jeg da tænker paa, hvorledes de igjen skal bringes omkring paa mange Steder i Landet (her er Elever fra Tonder, fra Mors, fra Ribe, og fra Fyen) hvorledes Luften skal renses, hvor disse Toner klinge, og at dette skeer ved mig, saa synes jeg, at, om jeg end ikke virkede Andet, saa var dette allerede nok, saa er jeg inderlig taknemlig, at dette Hverv er bleve mit. Og Gud skee Lov, de har Sands for Kæempeviserne, og holder af dem allesammen, De kan troe vort Chor er ikke saa ringe, og naar jeg da engang imellem selv tier og lader min Sjæl vugge af disse mine kjere Toner, som ere sammensmeltede med min hele Væren, og som frembringes af disse stærke ungdommelige friske Stemmer, og naar jeg veed, at det er Børn af Folkets egen Midte, som synger, saa er jeg glad, saa drømmer jeg om lykkelige Dage for Danmark. At jeg derimod ogsaa har følt og sørget over vore nuværende Forhold, tæenker jeg, De vil kunne see af medfølgende Sang, af hvilken jeg sender et Exemplar til Dem og eet til mine Rims tro Veninde Elise. Den er forfattet ved en offentlig Forelæsuing for Omegnens Beboere, som holdtes her paa Højskolen, og man har maaskee viist Dem den. Mit Foredrag var om Nordens Gudelære, af hvilken jeg fortalte et Par Sagn (om Ygdrasil og om Thor) og det lod til at interessere. Ved Bordet, som holdtes midtvejs paa Dagen, havde jeg den Glæde at kunne udbringe en Skaal for Grundtvig, som Danskhedens og FolkeHøjskolernes store Forkæmper, dog dette har De maaskee hørt. I Slutningen af denne Maaned skal vi til det igjen. Det bedrøvede mig at hore, at Elise var bleven "temmelig forstemt" ved at høre, at jeg sang Tydsk, skjøndt hun senere "blev fornuftig«, thi jeg veed nok, hvor meget den øjeblikkelige Folelse hos hende har at sige. Men hvorfor syntes hun ikke om det? Jeg begriber det, hun tænkte: (let er Svaghed, den ene sivaghed forer den anden med sig, nu er han veget et Skridt fra den golle Sag osv. Vil De da sige hende, at hvis hun kunde følge min Virksomhed herovre, hvis hun kunde se og hore, hvor begjærlig jeg griber enhver Lejlighed, jeg kan, til at indprcnte Eleverne, at 
al vor Fordærv er fornemmelig Tydsk, og til at udrive af deres Sjæl Troen paa Tydskens Fortræffelighed, Uundværlighed og Uskadelighed, som ikke endnu har faaet sit Banesaar, saa troer jeg, hun vilde vare tilfreds med mig, saa troer jeg, hun vilde tilgive mig, om jeg $\mathrm{i}$ et privat Hjem, hvor min Trods ingen Nytte vilde gjøre. der er en Smule føjelig, naar jeg kun er trofast, hvor det gjælder, og det er jeg. Jeg vil nu heller ikke tale om, at med Musik er det noget Andet, Musiken er, trods at der ogsaa gives national Musik, mere et Verdens Sprog, og jeg lader ikke være at lære Eleverne: „Inge Gjenbyrdsliv $i$ Norden «, skjøndt den har en tydsk Melodi. Men hvad nu min Modbydelighed for Tydsk Sprog angaaer, saa kommer der dog en Tid, naar jeg har lært mit Eget tilbunds at kjende, hvilket er nodvendigt, naar jeg ret skal kunne prise det, saa kommer clen Tid, da jeg maa bekvemme mig til at gjøre mig bekjendt med Tydsken, hvilket er nødvendigt, naar jeg ret skal kunne advare derimod. Men Fru Hage, De er vel allerede kjed af alt dette, og jeg skal kun tilføje, at al min Syngen tydske Sange indskrænker sig til, at Thomsen og jeg endnu ikke er bleven færdig med at indstudere (siger og skriver een), medens vi daglig synger en Snees Danske. Jeg har faaet en Deel af Weyses Kæmpeviser, og Fru Thomsen indstuderer Accompagnementerne; vi har i Dag sunget flere af dem. Dette vil vel ogsaa berolige Hanne (det gaar vel ikke an at sige Hanneliden), der synes at have næret Frygt for, at jeg var begyndt at hælde til Schleswigholsteinismen. Jeg holder en Gang om Ugen (Søndag Aften) Oplæsning for Eleverne, hvortil de møder efter Lyst. Jeg vælger Ting, som jeg kan være nogenlunde sikker paa, maa interessere. Begyndelsen gjordes med - Gunlaug Ormstunges Saga, som de hørte med Glæde. Mon Elise veed, at Grundtvig i en Bog, som hedder Saga, har oversat denne Fortælling. Efter Juul tænker jeg at ville læse Saxo for dem, i det mindste den forste Deel (Sagatexterne).

Jeg har det nu hyggeligt i mit lille Kammer, og Hønsene faaer ikke Lov at pille ved mit Blækhus, dette Blækhus, som 
Christopher forærede mig, og som beundres af Alle. Jeg har nu Tæpppe paa Gulvet. Min Moder og Saster havde foræret mig PuHer til Julegave, som pryder min Sopha. Over Sophaen hænger Skrænten, over Somkassen "Johammes den Dober«, forresten smykkes Væggen med Portrætter af Grundivig, Oehlenschläger, Holberg, Winther, Andersen, min Reol er vel fỵldt med Boger, saa De kan forestille Dem, at her er ganske hyggeligt. Thomsens og jeg pyntede et Juletra, hvortil indbodes Forstanflerens og Forpagterfolkene (Halvbønder) med deres lille Søn; jeg havile efter Opfordring skrevet et Par smaavers med nogle af Gaverne. Der var ikke videre ved dem, det bedste var med nogle trilske Digte af Herwegh til Forstanderen; det lød saalecles:

Af Herweghs Digte faier du her en Flok, med snak om ham jeg skal ej lang Tid dig genere, Han var en Tydsker - det er meer end nok, Jeg gider i let mindste ikke vide mere.

Har De Ly'st til at læse en Julehilsen til mine Forældre, vil Richardt kunne vise Dem den. At jeg savner mit Hjem, forstaaer De; man lærer at skønne derpaa, naar man har nydt lets Glæder $i$ et halvt Aar og saa flỵttes halvhundrede Mile bort ........

Nr. 4. Rødding Højskole, den 14. Febr. 1852.

[Fødselsdagshilsen til Fru Hage] - - - Jeg havde egentlig tiltænkt Dem en lille Digtning til den 18de, men det har desverre ikke varet mig muligt at faae nogen Ro dertil, da alle mine Kræfter have været tagne i Beslag til en Comedie, som nogle af Eleverne skal give Fastelavns Sønciag, og hvor jeg lleels er Instructeur, og har nu snart $i$ en Maaned holdt Prøve liver Aften, og desuden har jeg maattet skrive baade For- og Efterspil. De veed nok, at et lystigt Lag er mig ikke imod, og at I)eltagelse i Løjer, hvor man kan faae en hjertelig Latter, er inig kjer, men De veed ogsaa, at til at vare Formand for saa‘lamne Lojer duer jeg egentlig ikke; alligevel har Comedie- 
Instructionen moret mig ret godt, hvorimod For- og EfterspilsForarbejdelsen har været mig temmelig dræbende, thi til at gjøre det rigtig godt har jeg ikke Vid og Lune nok, og det har kedet mig grundigt at skulle skrive saadan noget Hverdagsmas og tom Fjas, som jeg har maattet, imidlertid kan det jo nok være, at det vil more Folk, som høre det saa overfladisk. og saa er jo da Hensigten opnaaet. Comedien, som vi skal have, er Holbergs arabiske Pulver.

Medens jeg taler om min poetiske Virksomhed, kan jeg dog sige Dem, at der hos Ploug ligger et Digt af mig til Grundtvig, som Tak for "Danskeren«, ved dens Ophør. Det har forresten snart ligget en Maaned hos ham; han har lovet at optage det, men jeg frygter næsten, han har glemt det; og hvis han husker det, saa er det jo rigtignok lidt kedeligt, at det bliver saa gammelt; imidlertid jeg vilde dog gjerne have, at det skulde komme, da jeg dog tænkte, at i det Mindste den gode Villie kunde glæde Grundtvig, nu faaer vi jo see Tiden an. Ploug har jo Saameget at tænke paa i denne Tid, at det jo ikke var saa sært, om han kunde glemme det; - Ja, hvad skal der dog blive af vore Forhold. Mon Monrad vil gaae saa vidt med sine Interpellationer, at han tilsidst tvinger Ministrene til at gaae af, og mon han da selv vil og kan gribe Tøjlerne? Eller skal denne usalige Politik vedblivende følges og Slesvig saaledes gives Holsteen i Vold, for det bliver dog Enden paa det; herovre ere vi meget bekymrede.

Her paa Skolen gaaer iøvrigt Alt sin jevne Gang; jeg arbejder med Lyst og jeg haaber ogsaa ikke ganske uden Held; jeg finder mig bedre og bedre i det noget eensomme Liv, og er glad for de Mennesker, jeg lever med. Nylig har vi havt offentligt Foredrag igjen - jeg fortalte Dem jo om de forrige - jeg talte om Baldursmythen, og det er en sand Fornøjelse at see, hvorledes Størstedelen af dem med Begjærlighed sluger hvert Ord, der bliver sagt. - Forstanderen, Hogsbro, søgte ligesom sidst at gjøre dem bekjendt med Goderne ver den frie danske Statsforfatning, for at vende deres Hjerter mod Danmark, thi 
selv heroppe har vi mange "Slesvig-Holstenere" og mange lunkne. Forresten haaber jeg, at de 35 Elever, som herfra spredes over Landet, i sin Tid dog skal gjøre nogen Nytte, og at Højskolen, om den kun kan bestaae, ikke skal virke uden Velsignelse, naar den kun vedbliver at være godt besøgt. Men Gud veed, hvorledes det skal gaae den, naar om et halvandet Aars Tid, Pengemidlerne er sluppet op, mon Regjeringen da, eller mon private Folk da vil hjælpe den, thi det var dog virkelig Synd og Skam, om den skulde gaae ind?

Hvad .jeg maa savne herovre, det er en ordentlig Gudstjeneste; jeg har kun været een Gang i Kirke, siden jeg forlod Sjælland, det var første Juledag, da tog Thomsens (Inspectøren og hans Kone) og jeg op til en Nabo Kirke. - - - Hvor længes jeg efter engang igjen at træde ind i Vartou Kirke. - - -

Nr. 5. Rødding Højskole, d. 19. April 1852.

- - Herovre er der i denne Tid betydeligt Liv for at sikkre Højskolens Tilværelse. De ved sagtens, at om 11/2 Aar ville de Midler være opbrugte, ved hvis Hjælp den nu bestaaer, og det gjælder nu, om Slesvigerne ville gjøre Noget for at opretholde den. Der er derfor udstedt en indtrængende Opfordring til Slesvigerne om at slutte sig til en "Forening for Rødding Højskole«, som har dannet sig, og dersom det viser sig, at der i Slesvig er nogen Interesse for Sagen, saa vil man henvende sig ogsaa til Kongerigets Indbyggere. Gid der maatte være Held med disse Bestræbelser, Pengene have jo i vore Tider mangesteds Vej, og det kan maaskee være vanskeligt nok at skaffe det Fornødne tilveje - ogsaa Regjeringen vil man naturligvis opfordre - men jeg antager, at de, som yde deres Hjælp dertil, de gjøre noget virkelig Godt, thi den Indlfydelse, Højskolen har paa sine Elever, og derigjennem paa storre Kredse, troer jeg ikke er saa ringe; forresten mangler jeg ikke Haab; paa den Generalforsamling, som holdtes i den forrige slesvigske Forening, hvor det besluttedes, at den skulde antage Rødding 
Højskoles Navn, var der ikke Faa samlede og af alle Stænder, gejstlige og verdslige Embedsmænd. Borgere og Bønder, som alle viste megen Interesse for Skolen. Det var fornøjeligt at sidde $i$ en saadan Forsamling, dansk i sind og Skind og fra forskjellige Kanter i Slesvig - og vist er det, at har vi end ikke, har vi end langt, langt fra vundet, hvad vi kunde onske i Forhold til det meget Blod. Bedre er det dog end før, og der vil være meget at staae imod med, naar vi tidlig eller seent skal til at tage fat igjen. Forresten synes det mig, som Slesvigerne finde sig bedre i Tingenes Tilstand, end man kunde onske, og Gud veed hvorlange Carl Moltke vil vente, inden han vender Vrangen ud; stoler man paa ham i Kjobenhavn, det vil sige paa hans Redelighed? I en af de første Maaneder, Maj eller Juni, vil der komme en Beretning ud om Højskolens Virksomhed; jeg skal snart ilav med min Deel deraf. Jeg haaber at kunne sende Dem et Exemplar, da jeg haaber, at det vil kume interessere Denı at see --

Ved den ovenomtalte Generalforsamling traf jeg et Par af Boisens Brødre, prægtige Mænd; den Ene, Harald Boisen, Præst i Medolden, og den Anden, Frits Boisen, Præst i Vilstrup. Meest talte jeg med den Sidste, da Harald Boisen rejste saa tidligt. Fin anden Mand, som jeg her lærte at kjende, var Hans Krüger fra Bevtoft, hvis Navn nok er Dem bekjendt; det er en prægtig, fordringsfri Mand (hvilket ikke kan siges om flere af de andre bekjendte danske Slesvigere, navnlig P. Chr. Koch og Laurids Skau) og han svarer ganske til den Forestilling, man fik om ham ved at høre om hans Færd $i$ den første oprørske Forsamling, hvor hall jo vovede at nedlægge Protest imod deres Foretagende, og mod, at det betegnedes som eenstemmig Beslutning. Ved Bordet udbragte jeg hans Skaal, som modtoges med meget Bifald. Hans Opoffrelse for Fædrelandets Sag har efter Sigende bragt hans Pengesager i en daarlig Forfatning, men der høres ikke et klagende Ord fra ham - - 
Nr. 6. Rødding Højskole, den 17. Juni 1852.

- Det glæder mig, at min trofaste Christian Richardt er Dem kjer; og hvad synes De om ham som Digter - inig forbavser hall ved enhver ny Ting, jeg seer af lıam, skjøndt hans Comedie kjender jeg ikke, det er mærkværdigt, hvilket Opsving han har taget; der er jo $i$ hans Vers en Dybde saavel i Tanke som i Folelse, og, hvad der skal gjøre ham til Digter, en Evne til at udtrykke dem, som lover Meget og allerede ikke er Lidet. Gud skee Lov for ham. Og nu jeg. Jeg, som har baaret paa de samme Haab og ikke kan slippe det (saaledes tor jeg tale til Dem) jeg, som har fulgtes med ham i de mange Aar, skal nu jeg - — Gud styre det til det bedste. Det har fornøjet mig, at De har syntes om mit "Sct. Helenes Kilde«, og dog jeg foler vel, at det har mange Mangler, vist er det, Chr. Richardt er løbet mig forbi, det gjælder at indhente ham. Der hører Kræfter til at lobe den op, som er kommen En forbi, og stundom synes mig, at jeg har denne Kraft, men til andre Tider er det mig, som om man gjerne kunde begrave mig strax. Verden vilde have ligemegen Nytte af mig, og jeg af Verden; men til Efteraaret, Fru Hage, til Efteraaret, saa er det, jeg skal vise, at Kraften har vundet Sejr, naar jeg først og fremmest alvorlig skal tage fat paa mine Studeringer; gid jeg ikke naa komme tilkort $\mathrm{i}$ den Prøve. Jeg haaber det ikke. - Der șnes da at være en højere Bestemmelse for, at mit lille Vers til Grundtvig ikke skulde naae til ham hverken ad offentlig eller ad privat Vej, og jeg tager mig det da heller ikke videre nær. Men Plougs Fremgangsmaade forstaaer jeg ikke. Jeg kunde godt begribe, at han $k \mathrm{u} d \mathrm{e} h$ a ve g l e m t de t; men jeg begriber ikke, naar han har husket det, hvorfor han har opsat det og opsat det, til det var for silde; hvorfor har han endelig ikke ladet mig det vide, det kunde han dog let igjennem min Broder; De maa dog tilstaae, det er en underlig Behandling. Og dog hvorfor skulde jeg forlange, at hall maatte have Interesse for mig længere, end mens han saae inig; han veed jo ikke, at han er En af dem, som jeg hænger 
ved med mest Kjærlighed af alle Mænd; og selv om han vidste det - den Følelse kan jo flere have; det kan han jo ikke være forpligtet til at bryde sig om. - Naa, jeg skulde ikke være bitter, egentlig har jeg jo glemt det for længe siden, nu kom det lidt op igjen, jeg har undertiden en Frygt for, at de, jeg holder af, skal glemme mig; den burde jeg ikke have i samme Øjeblik, som jeg har Beviis for, at jeg er husket af Nogle, og det af dem, af hvem jeg nødigst vilde glemmes - nej, De og Deres m a a ikke glemme mig _ _ -

Jeg føler mig bestandig vel i min Virksomhed herovre og troer, at kunde jeg blive noget længere $i$ den og samle nogen Erfaring, vilde jeg kunne blive brugbar; men det kan nu ikke være og bør ikke være. Af og til vil jeg savne Rødding, især hvis jeg skal have Timer i Kjøbenhavns Trælleskoler, efter at have været $\mathrm{i}$ dette Frihedens Hjem.

I Morgen drager jeg med Skolens Elever og Lærere til Sild (Sylt) paa en naturhistorisk otte Dages Tour; jeg glæder mig til at see denne ejendommelige Deel af Danmark og til at see Vesterhavet. Skolens Forstander Hogsbro er ikke med; han er i Kjøbenhavn for at tale med Clausen. Efter et Brev fra ham har Clausen lovet at sætte sig i Spidsen for den nye Pengeindsamling. 